\title{
Effects of metal contaminated soils on Eisenia fetida (Savigny) at Ludhiana (Punjab), India
}

\author{
Kulwinder Kaur* and Gurinder Kaur Sangha ${ }^{1}$ \\ College of Fisheries, Guru Angad Dev Veterinary and Animal Sciences University, Ludhiana 141004 (Punjab), \\ INDIA \\ ${ }^{1}$ Department of Zoology, Punjab Agricultural University, Ludhiana - 141004 (Punjab), INDIA \\ *Corresponding author. E-mail: kulwinder.sond@gmail.com
}

Received: April 17, 2014; Revised received: August 14, 2014; Accepted: October 20, 2014

\begin{abstract}
The soil in the vicinity of stream of Buddah Nullah in Ludhiana, Punjab has been found to be contaminated with heavy metals. The objective of this paper was to conduct studies with earthworm Eisenia fetida (Savigny) exposed to five soil samples collected from different sites around the stream of Buddah Nullah, since no such work has been done using earthworm as bio- indicator of soil pollution in that area to check the hazardous effects of heavy metals on soil organisms. Metal levels were recorded higher in contaminated soil samples than threshold concentration in soil of campus field. Adult E. fetida were exposed for a period of 80 days to evaluate the effects of elevated levels of heavy metals i.e. $0.29 \mathrm{ppm}, 4.18 \mathrm{ppm}$ and $2.29 \mathrm{ppm}$ for cadmium, lead and nickel respectively on survival, growth, morphology and reproduction. Significant effects were observed on survival, growth and reproduction of the tested organisms along with various morphological abnormalities such as tail shedding, body fragmentation and extrusion of coelomic fluid. But no such deformity was observed in worms reared in reference soil of university campus field. Detrimental effects on rates of cocoon production and hatchling emergence were observed and a significant delay was also recorded in production of cocoons and emergence of hatchlings. Results of the study indicated that reproductive end points were more sensitive to elevated metal levels in contaminated soil than survival or weight change.
\end{abstract}

Keywords: Eisenia fetida (Savigny), Heavy metals, Reproduction, Soil contamination, Survival

\section{INTRODUCTION}

Metal pollution affects the structure of soil invertebrate communities and disturbs the soil ecosystems. Earthworms are one of the first receptors to be affected by soil contamination. The bio-accumulative ability of earthworms enables them to be used as living organisms for the bio-monitoring of soil pollution (Hirano and Tamae, 2011). Elevated concentration of cadmium $(\mathrm{Cd})$, copper $(\mathrm{Cu})$, lead $(\mathrm{Pb})$ and zinc $(\mathrm{Zn})$ in soils can affect the density, viability, cocoon production, growth and sexual development of worms. Heavy metals cause mortality (Davies et al., 2003) and affect the population size, avoidance and species diversity of earthworms (Spurgeon et al., 2005). Reproduction is likely to be of particular importance in eco-toxicological assessment because of its influence on population dynamics. At high levels of heavy metals such as manganese (Mn), chromium (Cr), nickel (Ni) and cobalt (Co), significantly lower cocoon production and at medium levels, a time delay in cocoon production has been observed (Maleri et al., 2007). Reduction in cocoon production due to $\mathrm{Pb}$ and $\mathrm{Cd}$ exposure has also been reported in several studies in E. fetida (Zaltauskaite and Sodiene, 2010).
Keeping in view such detrimental effects of heavy metals on E. fetida, the present study was undertaken to assess the impact of metal contaminated soils collected from Buddah Nullah surroundings with particular reference to survival, morphology, growth and reproductive performance of adult worms of $E$. fetida. Contamination of soils with $\mathrm{Pb}, \mathrm{Cd}$ and $\mathrm{Ni}$ in Buddah Nullah surroundings is contributed by the establishment of dying industries and electroplating industries respectively.

\section{MATERIALS AND METHODS}

Present study was conducted at campus of Punjab Agricultural University (PAU), Ludhiana. Metal contaminated soils were collected on the same day from four different sites in the vicinity of Buddah Nullah, Ludhiana. The different sites included Chand Cinema, Sunder Nagar, Tajpur road and Shivpuri area around Buddah Nullah (Fig.1). All the soil samples were collected at least 2 meters away from the main stream.

Collection of soil samples and estimation of soil metal content: About $5 \mathrm{~kg}$ of soil was collected from top $2 \mathrm{~cm}$ layer at each site after removal of surface vegetation and litter in transparent polythene bags. All 


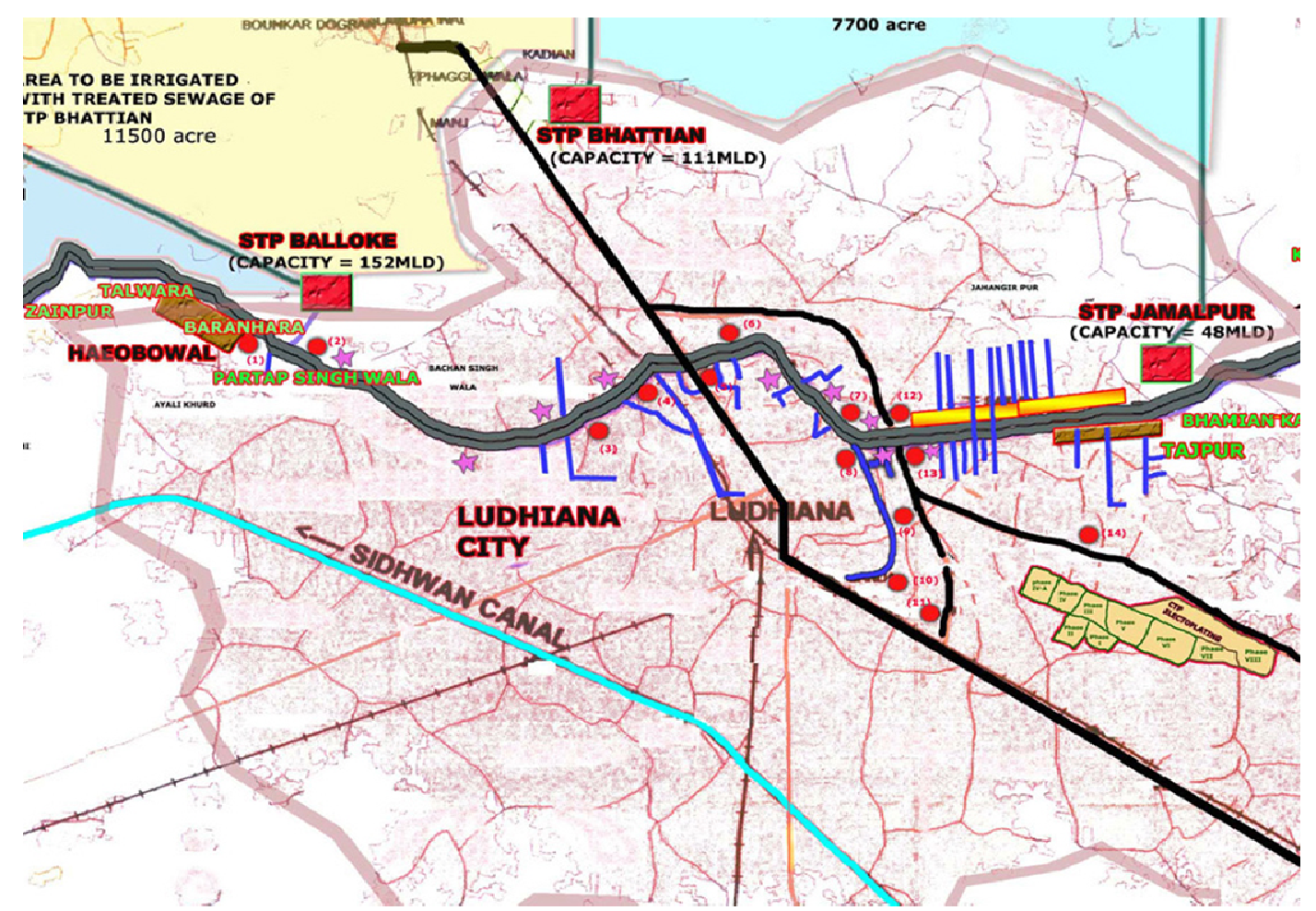

Fig. 1. Map of Buddah Nullah showing location of contaminated soil sites selected to collect samples (Sample collection sites are marked with blue arrow).

the bags were marked with respect to the sites from which the samples were collected. A control sample of soil was collected from an uncontaminated field in PAU campus. Soil aggregates were crushed while still damp and placed in a fan oven at $60^{\circ} \mathrm{C}$ for 2 days to dry. A subsample of soil was used for the determination of $\mathrm{Cd}, \mathrm{Pb}$ and $\mathrm{Ni}$ concentrations in the soils by flame atomic absorption spectrophotometry. $500 \mathrm{gm}$ of each soil sample was sieved, dried in an oven and placed in plastic boxes (four replicates of each sample) of size $20 \mathrm{~cm} \times 15 \mathrm{~cm} \times 4 \mathrm{~cm}$. Moisture content of the soil in replicate boxes was maintained at $65 \%$ of field capacity with distilled water. The soil was left to stabilize for 72 hours before the initiation of the experiment.

Study of reproductive parameters: Clitellar worms of E. fetida were obtained from the mass culture kept at the laboratory of the department. The selected worms were acclimatized for seven days. Five washed and weighed worms were placed into each of four replicate containers. After 3 hours they were checked to ensure that all the worms had burrowed into the soil. Feeding of worms comprised sprinkling $10 \mathrm{gm}$ of dried cattle manure per container per week. Containers were covered with plastic lid to avoid the moisture loss. Earthworms were separated by hand sorting, after which they were examined for different parameters. Rate of reproduction was assessed on the basis of the number of cocoons produced per adult worm at each sampling site (Sahu and Senapati, 1988).

Weight of all the worms was recorded weekly.
Mortality was determined by counting the number of dead earthworms. Worms were considered dead if they lacked any movement and did not respond to a definite tactile stimulus to the anterior end. Because earthworms tend to disintegrate quickly after death, absent worms were considered to have died (Maboeta et al., 2008). Cocoons were separated from each container by hand sorting. These cocoons were further used for studying different life stages of E. fetida. Cocoons were observed after every second day to observe hatching. Numbers of juveniles hatched per cocoon per week were also recorded in all samples of soil.

Statistical analysis: The data was statistically analyzed by analysis of variance (ANOVA) using computer software CPCS1.

\section{RESULTS AND DISCUSSION}

Composition of soil: Results of analysis of soil composition are depicted in Table 1. Metals' level at PAU campus were within the range typical for an uncontaminated soil. Maximum concentration of $\mathrm{Cd}$ was found in soil sample 4 while highest concentration of $\mathrm{Pb}$ i.e. 4.18 ppm and $\mathrm{Ni}$ was observed in soil sample 2. i.e. 2.29 ppm. Contamination of soils with $\mathrm{Pb}, \mathrm{Cd}$ and $\mathrm{Ni}$ in Buddah Nullah surroundings is contributed by the establishment of textile industries and electroplating industries respectively in the surrounding areas of Buddah Nullah. The increase in heavy metal content of soils with continuous application of sludge/sewage water has also been reported (Brar et al., 2002).

The results also find support from work of Dowdy et 


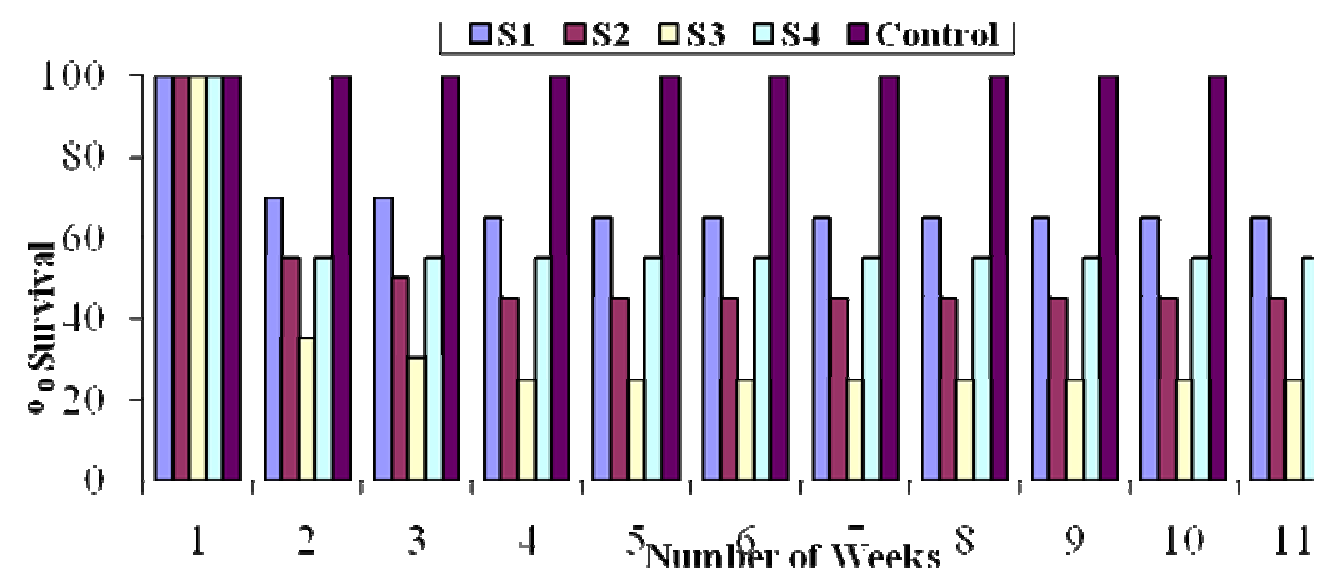

Fig. 2. Percent survival of adult E. fetida reared in different soil samples.

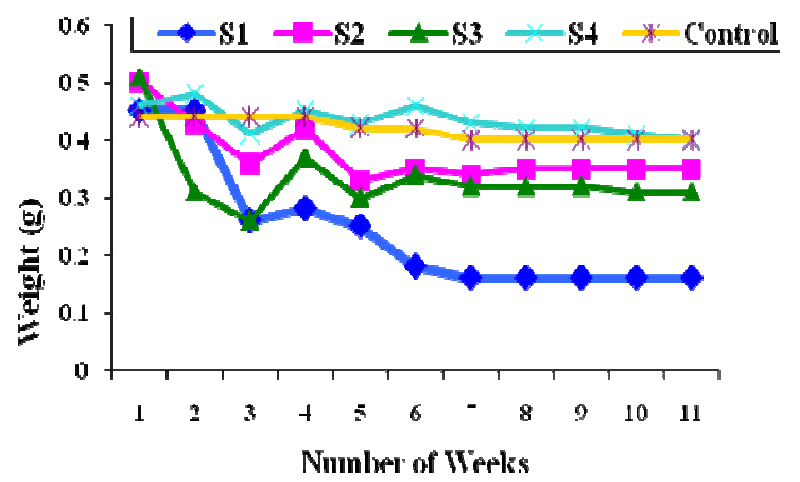

Fig. 3. Weekly changes in body weights $(g)$ of adults of $E$. fetida reared in different soil samples.

al. (1991) who found that massive sludge additions (765 mg/ha on dry weight basis) over a period of 14 years resulted in an increased concentration of $\mathrm{Cd}, \mathrm{Zn}$ and $\mathrm{Cu}$ in Apl genetic horizon. Kuhad et al. (1989) observed higher accumulation of metals such as Zn, $\mathrm{Cu}, \mathrm{Mn}$ and iron (Fe) in the surface layer of the sewage irrigated soils of Sonipat district of Haryana.

Survival and morphology: Tested worms survived well in the control sample of soil taken from PAU campus and there was no mortality seen in this soil sample (Fig. 2), while mortality in adult worms was observed in all the contaminated soil samples. Haghparast et al. (2009) has observed that worms reared in soils contaminated with $\mathrm{Pb}, \mathrm{Zn}$ and $\mathrm{Cu}$ showed increased mortality.

High level of aluminum in acidic red soil was found harmful to E. fetida (Zhang et al., 2013). Various morphological abnormalities were observed in worms reared in all the four contaminated soil samples. Percentage of worms having morphological abnormalities is given in Table 2. Similar abnormalities have been reported in other studies also where soils were contaminated with heavy metals such as $\mathrm{Cr}$, $\mathrm{Co}, \mathrm{Mn}$ and $\mathrm{Pb}$ (Rao et al., 2003; Maleri et al., 2007).

Changes in body weight: In control sample of soil taken from PAU campus, non-significant decrease in body weight was observed, while a discontinuous pattern of body weight was observed in worms reared in all the contaminated samples of soil as shown in Fig. 3. Growth of earthworm Octodrilus complanatus was also found affected by aluminum level and aluminum caused reduction in earthworm protein content (Bilialis et al., 2013).

E. fetida has been found the most sensitive species with decreased weight among E. albidus, E. crypticus and E. fetida in industrial waste material avoidance tests conducted by Kobeticova et al. (2010). Relationship between arsenic (As) contamination of abandoned mine sites in Korea and the average weight of earthworms was found significant by Shin et al. (2007). It was observed by Khalil (2013) that earthworms Allolobophora caliginosa feed less and Pheretima hawayana escaped into their burrows when exposed to arsenate. Miguel et al. (2012) revealed in a study that weight and mortality of worms were significantly affected by high levels of heavy metals.

Cocoon production rates: The cocoons were

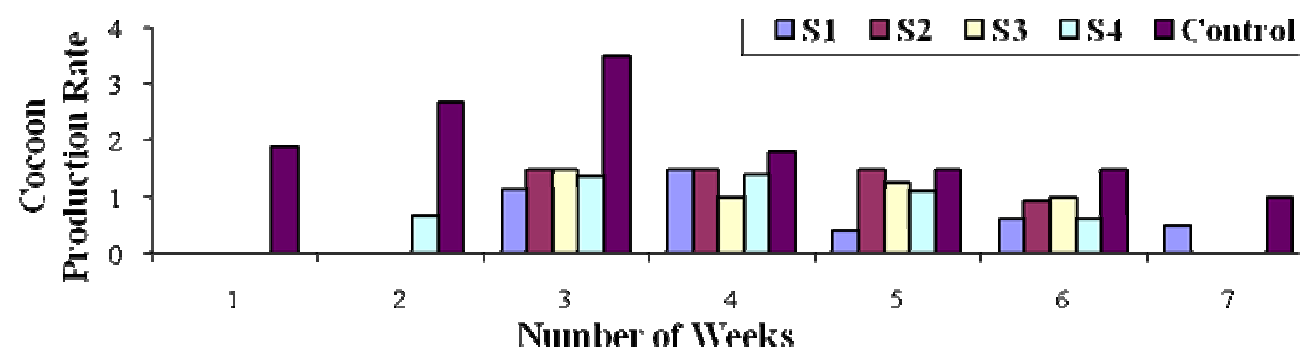

Fig. 4. Cocoon production rate of adult E. fetida reared in different soil samples. 


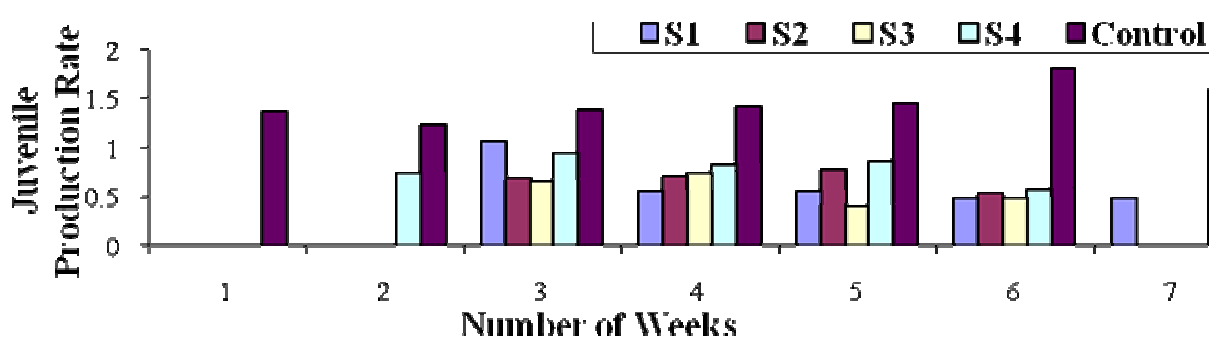

Fig. 5. Juvenile production rate of adult E. fetida reared in different soil samples.

Table 1. Concentrations of different heavy metals in soil samples.

\begin{tabular}{cccc}
\hline \multirow{2}{*}{ (Soil Sample) } & \multicolumn{3}{c}{ Concentration of heavy metals (ppm)* } \\
\cline { 2 - 4 } & Cadmium $(\mathbf{C d})$ & Lead $(\mathbf{P b})$ & Nickel $(\mathbf{N i})$ \\
\hline S1 & 0.23 & 3.86 & 1.87 \\
S2 & 0.18 & 4.18 & 2.29 \\
S3 & 0.25 & 3.35 & 1.43 \\
S4 & 0.29 & 3.96 & 2.14 \\
Control & 0.20 & 1.75 & 0.50 \\
\hline
\end{tabular}

Table2. Various abnormalities observed in adult E. fetida in uncontaminated and metal contaminated soil samples.

\begin{tabular}{cccc}
\hline Soil sample & Tail shedding (\%) & Fragmentation $(\boldsymbol{\%})$ & Extrusion of coelomic fluid (\%) \\
\hline (S1) & +5 & +15 & +100 \\
$(\mathrm{~S} 2)$ & - & +20 & +100 \\
$(\mathrm{~S} 3)$ & - & +55 & +100 \\
$(\mathrm{~S} 4)$ & +5 & +45 & +100 \\
(Control) & - & - & - \\
\hline
\end{tabular}

+ (Plus) Indicates presence and - (Minus) indicates absence of characteristic

collected after one week when adult animals were reared in control soil sample taken from PAU campus (Fig.4). The total number of cocoons was significantly lower in all the contaminated soil samples as compared to control sample of soil and minimum number of cocoons was produced in sample 3 , probably due to the high concentration of heavy metals $\mathrm{Pb}$ and $\mathrm{Cd}$ in this sample of soil. Delayed cocoon production in all the contaminated soil samples showed that cocoon production rates were particularly sensitive during early period of reproduction as also reported by Spurgeon and Hopkin (1995).

The detrimental effect of cadmium on cocoon production by E. fetida has also been recorded by Garg et al. (2009). Owojori et al. (2009) also observed significant effect on cocoon production with combination of sodium chloride $(\mathrm{NaCl})$ and $\mathrm{Cu}$. Fordsmand et al. (1998) recorded the reproduction as most sensitive parameter being reduced at high $\mathrm{Ni}$ concentration in soil. Acute effects of $\mathrm{Cd}$ and $\mathrm{Cu}$ on the reproductive rate of $E$. fetida has also been revealed in studies by Spurgeon et al. (1994). Reduction in cocoon production due to $\mathrm{Pb}$ and $\mathrm{Cd}$ exposure has also been recorded (Savard et al., 2007).

Emergence of hatchlings: In control sample of soil taken from PAU campus, hatchlings started emerging 2 weeks earlier than all the contaminated soil samples. Total number of hatchlings emerged was also more in case of control uncontaminated soil sample (Fig.5).
Maximum hatchling production rate was found in control soil sample.

Lesser number of hatchlings in each contaminated soil sample as compared to control soil sample is probably due to the elevated level of heavy metals $(\mathrm{Cd}, \mathrm{Pb}$ and Ni). Gupta et al. (1999) also demonstrated the low hatchling production rate of cocoons in Metaphire posthuma reared in soil contaminated with cadmium, which shows the ill effects of $\mathrm{Cd}$ on the embryonic development of earthworms. Both number and rate of hatchling production has been found affected in the metal contaminated soils. The increased incubation period of cocoons has also been observed by Panda et al. (1999) in study of $\mathrm{Zn}$ accumulation and its effects on growth and reproduction of earthworm Drawida willsi, a dominant earthworm in Indian crop fields. In agreement with other studies on E. fetida, cocoon viability was affected negatively by $\mathrm{Pb}$, making this a sensitivity endpoint (Maboeta et al., 1999).

\section{Conclusion}

Results of the study provide evidence that reproduction of E. fetida is more sensitive than survival and weight change. Although survival, morphology and growth were found affected in adult earthworms but acute effects were seen on reproduction i.e. cocoon production and juvenile production. Findings of the present study can be used to plan and implement remediation strategies for the metal polluted soils in 
areas where risk of soil metal contamination is associated with population dynamics of soil invertebrates.

\section{REFERENCES}

Bilialis, D., Tzortzi, I., Vavoulidou, E., Karkanis, A., Emmanouel, N., Efthimiadou, A., Katsenios, N., Patsiali, S. and Dellaporta, L. (2013). Effects of aluminum and moisture levels on aluminum bioaccumulation and protein content in the earthworm. Octodrilus complanatus. Journal of Soil Science and Plant Nutrition, http://dx.doi.org/10.4067/ S0718-95162013005000067

Brar, M. S., Khurana, M.P.S. and Kansal, B. D. (2002). Effects of irrigation by untreated sewage effluents on the micro and potentially toxic elements in soils and plants. Proc. $17^{\text {th }}$ World Congress Soil Sciience, Bangkok, Thailand 4(198):1-10.

Davies, N. A., Hodson, M. E. and Black, S. (2003). The influence of time on lead toxicity and bioaccumulation determined by the OECD earthworm toxicity test. Environmental Pollution, 21:55-61.

Dowdy, R. H., Lattreell, J. J., Hinesly, T. D., Grassman, R. B. and Sullivan, D. L. (1991). Trace metal movement in an aericochraqualf following 14 years of annual sludge application. Journal of Environmental Quality, 20:119-23.

Fordsmand, S. J. J., Weeks, M. J. and Hopkin, S. P. (1998). Toxicity of nickel to the earthworm and the applicability of the neutral red retention assay. Ecotoxicology, 7(5): 291-95

Garg, P., Satya, S. and Sharma, S. (2009). Effect of heavy metal supplementation on local (Allolobophora parva) and exotic (Eisenia fetida) earthworm species: A comparative study. Journal of Environmental Science and Health, 44(A): 1025-32.

Gupta, S. K., Murthy, R. C. and Saxena, D. K. (1999). Effect of cadmium on the hatching of Metaphire posthuma cocoons. Biomedical and Environmental Sciences, 12 (1): 50-53.

Haghparast, J. R., Gochin, A. and Kahneh, E. (2009).To study effect of heavy metals contamination on growth of earthworm (Eisenia fetida) in two calcareous and acidic soils. Biophysical and socio economic frame conditions for the sustainable management of natural resources. Topentag, Hamburg, Germany.

Hirano, T. and Tamae, K. (2011). Earthworms and soil pollutants. Sensors (Basel), 11(12):11157-67

Khalil, A. M. (2013). Ecotoxicological bioassays of the earthworms Allolobophora caliginosa savigny and Pheretima hawayana rosa treated with arsenate. On Line Journal of Biological Sciences, 13(3): 99-105.

Kobeticova, K., Hofman, J. and Holoubek, I. (2010). Ecotoxicity of wastes in avoidance tests with Enchytraeus albidus, Enchytraeus crypticus and Eisenia fetida (Oligochaeta). Waste Management, 30(4): 558-64.

Kuhad, M. S., Malik, R. S., Singh, R. and Singh, A. (1989). Studies on mobility and accumulation of heavy metals in agricultural soils receiving sewer water irrigation. Journal of Indian Society of Soil Science, 37: 290-94.

Maboeta, M. S., Reinecke, A. J. and Reinecke, S. A. (1999). Effects of low levels of lead on growth and reproduction of Asian earthworm Perionyx excavatus (Oligochaeta). Ecotoxicology and Environmental Safety,
44(3): 236-40.

Maboeta, M. S., Rensburg, V. L., Jansen, P. J. and Rensburg, V. (2008). Earthworm (Eisenia fetida) bioassay to assess the possible effects of platinum tailings disposal facilities on the environment along a gradient. Applied Ecology and Environment Research, 6(2): 13-19.

Maleri, R., Reinecke, S. A., Przybylowicz, J. M. and Reinecke, A. J. (2007). Growth and reproduction of earthworms in ultramafic soils. Archieves of Environmental Contamination and Toxicology, 52(3): 363-70.

Miguel, A., Domínguez, C. Z., Hernández, E. S., Aidé, M., Huerta, T., De la Luz, X. M., Rodríguez, N., Barajas, C. E. and Vela, A. F. (2012). Effect of the heavy metals $\mathrm{Cu}, \mathrm{Ni}, \mathrm{Cd}$ and $\mathrm{Zn}$ on the growth and reproduction of epigeic earthworms (E. fetida) during the vermistabilization of municipal sewage sludge. Water Air and Soil Pollution, 223(2):915-931.

Owojori, J. O., Reinecke, A. J. and Rozanov, A. B. (2009). The combined effects of salinity and copper on the earthworm Eisenia fetida. Applied Soil Ecology, 41(3): 277-85.

Panda, R., Pati, S. S. and Sahu, S. K. (1999). Accumulation of zinc and its effects on the growth, reproduction and life cycle of Drawida Willsi (Oligochaeta), a dominant earthworm in Indian crop fields. Biology and Fertility of Soils, 29: 419-23.

Rao, J. V., Kavitha, P. and Rao, A. P. (2003). Comparative toxicity of tetraethyl lead and lead oxide to earthworms, Eisenia fetida. Environmental Research, 92(3): 271-76.

Sahu, S. K. and Senapati, B. K. (1988). Alternative proposals for quantification of reproduction in a tropical earthworm.Tropical Ecology, 29: 6-14.

Savard, K., Berthelot, Y., Auroy, A., Spear, P. A., Trottier, B. and Robidoux, P. Y. (2007). Effects of HMX-lead mixtures on reproduction of the earthworm Eisenia Andrei. Archieves of Environmental Contamination and Toxicology, 53: 351-58.

Shin, K., Kim, J. and Kim, K. (2007). Earthworm toxicity test for the monitoring arsenic and heavy metal containing mine tailings. Environmental Engineering Science, 24(9): 1257-65.

Spurgeon, D. J., Hopkin, S. P. and Jones, D. T. (1994). Effects of cadmium, copper, lead and zinc on growth, reproduction and survival of the earthworm Eisenia fetida (Savigny): Assessing the environmental impact of point-source metal contamination in terrestrial ecosystem. Environmental Pollution, 84: 123-30.

Spurgeon, D. J. and Hopkin, S. P. (1995). Extrapolation of the laboratory based OECD earthworm toxicity test to meta contaminated field sites. Ecotoxicology,4(3):190-205.

Spurgeon, D. J., Ricketts, H., Svendsen, C., Morgan, A. J. and Kille, P. (2005). Hierarchial responses of soil invertebrates (earthworms) to toxic metal stress. Environmental Science and Technology, 39: 5327-34.

Zaltauskaite, J. and Sodiene, I. (2010). Effects of total cadmium and lead concentration in soil on the growth, reproduction and survival of earthworm Eisenia fetida. Ekologia, 56(1-2): 10-16.

Zhang, J., Yu, J., Ouyang, Y. H. and Xu, H. (2013). Responses of earthworms to aluminum toxicity in latosol. Environmental Science and Pollution Research, 20(2): 1135-1141. 